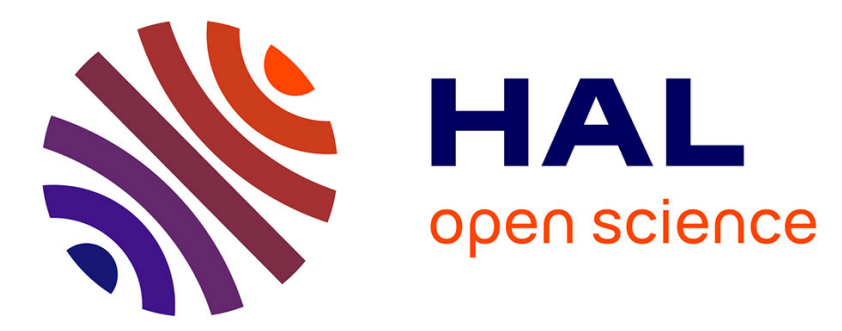

\title{
The NO2 spectrum in the 12500-16100 cm-1 energy range obtained by intracavity laser absorption spectroscopy
}

R. Georges, A. Delon, R. Jost, F. Bylicki, A. Campargue, M. Chenevier, F. Stoeckel, J. Vetterhöffer

\section{To cite this version:}

R. Georges, A. Delon, R. Jost, F. Bylicki, A. Campargue, et al.. The NO2 spectrum in the 12500$16100 \mathrm{~cm}-1$ energy range obtained by intracavity laser absorption spectroscopy. Journal de Physique IV Proceedings, 1994, 04 (C4), pp.C4-677-C4-677. 10.1051/jp4:19944178 . jpa-00252637

\section{HAL Id: jpa-00252637 https://hal.science/jpa-00252637}

Submitted on 1 Jan 1994

HAL is a multi-disciplinary open access archive for the deposit and dissemination of scientific research documents, whether they are published or not. The documents may come from teaching and research institutions in France or abroad, or from public or private research centers.
L'archive ouverte pluridisciplinaire HAL, est destinée au dépôt et à la diffusion de documents scientifiques de niveau recherche, publiés ou non, émanant des établissements d'enseignement et de recherche français ou étrangers, des laboratoires publics ou privés. 


\title{
The $\mathrm{NO}_{2}$ spectrum in the $12500-16100 \mathrm{~cm}^{-1}$ energy range obtained by intracavity laser absorption spectroscopy
}

\author{
R. GEORGES, A. DELON, R. JOST, F. BYLICKI* A. CAMPARGUE** , M. CHENEVIER ${ }^{* *}$, \\ F. STOECKEL** and J. VETTERHÖFFER ${ }^{* *}$
}

Laboratoire des Champs Magnétiques Intenses, CNRS, BP. 166, 38042 Grenoble cedex, France

${ }^{*}$ Institute of Physics, Nicholas Copernicus University, ul. Grudziadzka 5, 87100 Torun, Poland

${ }^{* *}$ Laboratoire de Spectrométrie Physique, Université Joseph Fourier de Grenoble, BP. 87, 38402 Saint Martin d'Hères cedex, France

We present spectroscopic results obtained on $\mathrm{NO}_{2}$ molecules with the IntraCavity Laser Absorption Spectroscopy (ICLAS) technique in which the gas sample is rotationally cooled in a supersonic slit jet.

Our goal is to observe the vibronic levels of $\mathrm{NO}_{2}$ from 10000 to $16500 \mathrm{~cm}^{-1}$ in order to study the transition from the regular to the chaotic behavior. The high sensitivity of the ICLAS technique is well adapted to the study of the $\mathrm{NO}_{2}$ absorption spectrum which is very weak in the near I.R.. Morever the rotational congestion observed at room temperature forbids rotational analysis. This spectral congestion can be overcome by using the cocling effect of a supersonic expansion. The geometry of a slit jet (instead of a pinhole jet) is well adapted to absorption experiment : the expansion of a mixture of $\mathrm{NO}_{2}(1 \%)$ and argon through a slit jet (thickness : 10 microns, length : $24 \mathrm{~cm}$ ) reduces the rotational temperature down to about $10 \mathrm{~K}$. So we have combined the high sensitivity of the ICLAS technique with the rotational cooling obtained by a supersonic slit jet.

The high sensitivity of the ICLAS technique is governed by the generation time, time during which the mode competition occurs in the laser. A typical generation time of $100 \mu \mathrm{sec}$ corresponds to an equivalent pathlength of $7 \mathrm{~km}$. The resolution, limited by a two meters monochromator, is $0.05 \mathrm{~cm}^{-1}$.

We have studied with a dye laser the $12500-16100 \mathrm{~cm}^{-1}$ energy range in which 156 cold bands have been observed. They represent about $65 \%$ of the total number of bands predicted by using a 24 parameters Dunham expansion. These 24 parameters have been determined by a fit of about 300 levels observed by LIDFS in the $0-12000 \mathrm{~cm}^{-1}$ energy range.

We will access to the $10000-13000 \mathrm{~cm}^{-1}$ energy range with ICLAS technique using a new Titanium-Sapphire ( $\mathrm{Ti}: \mathrm{Al}_{2} \mathrm{O}_{3}$ ) laser developped by $\mathrm{A}$. Charvat and presented in a joint poster. 